\title{
ПОЕМА Т. ШЕВЧЕНКА НАЙМИЧКА \\ ТА ЙОГО ОДНОЙМЕННА ПОВІСТЬ: ДО ПОРІВНЯЛЬНИХ СТУДІЙ І. ФРАНКА
}

\author{
ЖАННА ЯНКОВСЬКА \\ Національний університет „Острозька академія”, Острог - Україна \\ zanna.malva@gmail.com; ORCID: 0000-0002-7846-2796 \\ POEMAT T. SZEWCZENKI НАЙМИЧКА \\ I POWIEŚĆ POD TAKIM SAMYM TYTUŁEM: \\ BADANIA PORÓWNAWCZE I. FRANKI \\ ŻANNA JANKOWSKA \\ Uniwersytet Narodowy “Akademia Ostrogska”, Ostróg — Ukraina
}

SRTESZCZENIE. Twórczość Tarasa Szewczenki ma dla narodu ukraińskiego szczególne znaczenie, ponieważ zawiera w sobie zarówno mentalne, jak i psychologiczne oraz archetypiczne kody. Każde nowe jej odczytanie siłą rzeczy opiera się na dotychczasowych ustaleniach badaczy, jednak zawiera w sobie także nową perspektywę. Aktualność niniejszej pracy polega na tym, żejest ona dopełnieniem analizy porównawczej autorstwa Iwana Franki, który w swoim wykładzie habilitacyjnym poruszył problematykę poematu Наймичка T. Szewczenki oraz opowiadania o tym samym tytule. Badania zostały przeprowadzone w aspekcie komparatystycznym. Nie kwestionując wagi badań klasyka, autorka postawiła sobie za zadanie pogłębić pewne jego ustalenia na temat omawianych utworów Kobziarza, odwołując się do postulatów współczesnej metodologii literaturoznawczej. We wnioskach znalazły się aktualizacje dotyczące odrębnych faktów powiązanych z czasem i kolejnością pisania poematu i opowiadania. Oprócz tego zaprezentowano również propozycje rozwiązań wielu zadań analitycznych, które postawił przed sobą I. Franko (charakterystykę chronotopu, analizę porównawczą bohaterów utworów itd.).

Słowa kluczowe: poemat T. Szewczenki Наймичка, powieść T. Szewczenki Наймичка, wykład habilitacyjny I. Franki, analiza porównawcza 


\title{
TARAS SHEVCHENKO'S POEM NAIMYCHKA AND HIS HOMONYMOUS NOVELETTE: A CONTRIBUTION TO IVAN FRANKO'S COMPARATIVE STUDIES
}

\author{
ZHANNA YANKOVSKA \\ The National University of Ostroh Academy, Ostroh — Ukraine
}

\begin{abstract}
Taras Shevchenko's works are iconic to Ukrainians as they contain mental, psychological, and archetypal codes of national existence as an ethnicity. At every stage of their analysis there is a need to address the research of the past as well as resort to their new comprehension. The topicality of this research consists in interpretation and amplifying of Ivan Franko's comparative analysis of Taras Shevchenko's poem Naimychka (The Servant Girl) and his homonymous novelette presented by the scholar in his habilitation lecture (given at Lviv University on February 18, 1895). The research is conducted within comparative literature studies framework. Leaving aside the unquestionable importance and weight of the studies by the classic writer, the purpose of this paper is to expand comparative experiments with the abovementioned Shevchenko's works with consideration of current advances in research methods. A valuable finding of the paper is refinement of some facts, related to the time and sequence of the poem's and the novelette's appearance, as well as solving certain analytical problems stated by I. Franko (defining chronotope, comparing descriptions and qualities of characters etc.), which can be continued in a prospective research.
\end{abstract}

Keywords: Taras Shevchenko's poem and novelette Naimychka (The Servant Girl), Ivan Franko's habilitation lecture, comparative characteristics

Б агатогранна й різноманітна творчість Тараса Шевченка для українців не просто знакова — вона концентрує ментальні, психологічні й архетипні коди національного буття. Саме тому, очевидно, уже більше як півтора століття вона актуальна і, як видається, залишатиметься такою завжди. Безумовно, важливою сторінкою для розкриття та розуміння Т. Шевченка як поета є і його прозові та драматичні твори, а також мистецький доробок як художника, безпосередньо пов'язаний з літературною творчістю. Цей зв'язок на сьогодні ще недостатньо висвітлено в наукових дослідженнях. Спадщина Кобзаря настільки глибока, що, незважаючи на численні праці, у яких учені з огляду на вже здійснені наукові дослідження та вироблені погляди, що відповідають конкретному історичному періоду, і далі намагаються аналізувати й тлумачити їі. Утім завжди залишається простір для досліджень та відкриттів. Це можна розуміти так, що кожне нове покоління на своєму етапі науково потрактовує творчість митця й ще на одну сходинку наближається до осягнення його як генія, непересічного таланту. 
Перерахувати праці вчених, які аналізували твори Т. Шевченка, - марне намагання. Усе ж зазначмо, що від перших відгуків П. Куліша, М. Костомарова та інших письменників сер. XIX ст. до нинішнього часу доробок Кобзаря досліджували Ю. Барабаш, О. Вертій, Г. Грабович, І. Дзюба, О. Засенко, Н. Зборовська, Т. Комаринець, М. Коцюбинська, Н. Крутикова, С. Нахлік, В. Погребенник, Ф. Погребенник, Г. Сидоренко, В. Смілянська, І. Франко, Є. Шабліовський, М. Шамота, В. Шевчук, В. Шубравський, Д. Чалий, Н. Чамата й багато інших.

Сьогодні у зв'язку з розширенням меж аналізування літературних творів, під час якого актуалізуються компаративні студії, спирання на інші гуманітарні науки, а також виникненням та розвитком різноманітних інтердисциплінарних наукових галузей художні тексти часто інтерпретують, залучаючи категорії філософської та літературної герменевтики, етнофілософії, етноестетики, етностилістики та інших бінарних напрямів, що плідно застосовують окремі сучасні науковці, зокрема й для аналізування творчості Т. Шевченка (О. Вертій, П. Іванишин, Я. Гарасим та ін.).

У різних жанрах своєї творчості Т. Шевченко неодноразово розробляє тему про долю покритки в традиційному українському суспільстві його часу. Творами, у яких вона розкривається дуже драматично, є його поема Наймичка [Шевченко 1985: 240-251] та однойменна російськомовна повість [Шевченко 1978, 4: 52-121]. І. Франко в габілітаційному викладі Наймичка Т. Шевченка, називаючи їі темою “пониження женщини” [Франко 1981, 29: 464], зазначав, що вона „занімала його досить довго і що він обробив їі два рази: раз в повісті, написаній мовою російською, густо перемішаною зворотами українськими, а другий раз в поемі, написаній по-українськи" [Франко 1981, 29: 447]. Учений наголосив, що таке порівняння дає можливість ,заглянути глибоко в робітню творчого генія Шевченкового" [Франко 1981, 29: 447]. Одночасно він опонує д-ру О. Колессі (погоджуючись із окремими доказовими судженнями дослідника) в тому, що, аби пізнати Шевченка (більше його “методу”), не варто порівнювати цього митця з А. Міцкевичем, В. Жуковським, І. Козловим, О. Пушкіним чи іншими іноземними поетами, бо метод Кобзаря був зовсім інший. I ця відмінність, додамо, полягала насамперед у закоріненні в українську народну традицію. Тому, опрацювавши обидва Шевченкові твори, I. Франко висловив оригінальні думки стосовно їхнього порівняння. До того ж нині, ураховуючи досягнення сучасної компаративістики як полігалузевого напряму та зважаючи на згадану інтердисциплінарність, можемо посутньо доповнити й уточнити Франкові студії, що і є метою цієї наукової розвідки, яка належить до початкових студій у заданому напрямі.

Тривалий час достеменно було невідомо, який із зазначених творів Кобзаря написаний раніше - повість чи поема. Детально проаналізувавши їх, 
I. Франко стверджував, що першою була написана повість, а потім текст викристалізувався в поему [Франко 1981, 29: 448-449]. Таке „констатування хронологічного первенства повісті” [Франко 1981, 29: 451] було важливим для вченого, оскільки саме це й визначало шлях аналізу творчого методу Т.Шевченка. Тому дослідник відзначав стриманість та майже філігранну лаконічність поеми в описах героїв та особливо природи (порівняно 3 повістю), одночасно констатуючи й значно вищу мистецьку вартість поетичного тексту, що $є$ незаперечним фактом. Для ілюстрації своєї думки він як доказ використовує епізод, у якому порівнює описи подій на хуторі перед тим, як Трохим і Настя (у поемі) та Яким і Марта (у повісті) знайшли дитину: „Поет тут і там снує ту саму провідну думку, та в поемі виказує її коротко, без усіх лишніх подробиць, але способом таким пластичним та ясним, а при тім в такім зв'язку з попередньою рефлексією, що тих кілька рядків робить далеко глибше і суцільніше враження, ніж аналогічна сцена в повісті, де реалізм подробиць шкодить суцільності враження. Так і чуємо, порівнюючи ті і многі інші місця обох сих творів, що поет наш, свідомо чи несвідомо, держався тої думки, що поезія - то згущена, сконцентрована, скристалізована дійсність” [Франко 1981, 29: 457].

У другому епізоді габілітаційного викладу вчений апелює до іншого доказу щодо часу написання поеми та повісті. Маючи на увазі поему, він докоряє Т.Шевченку у відірваності зображених подій від конкретної місцевості, тобто занадто великій узагальненості стосовно хронотопу: „Перше явище, яке нам в ній впадає в око, се цілковитий брак локального колориту. Степ покритий туманом, з котрого виринає могила — отсе крайобраз прологу; гайок, ставок, млин, пасіка і хутір - отсе місце, де відбуваються дальші події поеми. Де, в якій стороні широкої України се діється - про се ані слова” [Франко 1981, 29: 449]. І. Франко, як відомо, твердо відстоював реалістичні засади зображення і як письменник, поет, і як літературний критик. Тому, підсумовуючи свої думки з приводу зазначеного, назвавши такий пейзаж “затертим”, дослідник зрезюмував: „Отсей брак локального колориту я вважаю важним доказом того, що повість «Наймичка» написана була перед поемою” [Франко 1981, 29: 450]. Проте вже вчені XX ст. довели, що з відомостями стосовно дат написання поеми та повісті було якраз навпаки: спершу, 1845 р. (згідно 3 автографом - „13 ноября 1845, в Переяславі”), була написана поема. А, як зазначено в Коментарях до габілітаційного викладу дослідника, „цитована I. Франком дата в автографі повісті «Наймичка» - фіктивна. Повість датується орієнтовно 1852-1853 рр.” [Коментарі, Франко 1981, 29: 635]. Очевидно, захоплений удалим сюжетом та композицією поеми, Т. Шевченко сам вирішив розширити їх та, змінивши окремі обставини, додав певні подробиці й перейменував окремих героїв. Наголосімо, що як для свого часу аналіз I. Франка є детальним та доказовим, особливо це стосується текстологіч- 
них порівнянь. Однак маємо намір унести деякі уточнення, що актуальні вже 3 огляду грунтовних засад сучасної методології та наукових досягнень. Скажімо, зважаючи на заявлені в цій статті дослідницькі методи, можна дещо по-іншому потрактувати окреслені в поемі та означені вченим топоси буття. По-перше, через “неномінацію” конкретного місця подій, але окреслення одвічних пріоритетів життєперебування, яким надавали перевагу українці (хутір, пасіка, млин, ставок, власна земля), помітний крок поета до типізації ідеального національного простору та зображуваного явища, що є логічним для поетичного епічного твору й української літератури періоду романтизму загалом, адже вона була дуже близька до фольклорної традиції та часто ідеалізувала життя народу, зокрема і його буттєві топоси. Складники цього простору як універсальні архетипи викристалізував та охарактеризував у своїх працях Архетипи української культури, Архетипи української ментальності та Дім - Поле - Храм С. Кримський [Кримський 2008, 2006, 2010], який услід за К. Юнгом (Архетипи і колективне несвідоме) [Юнг 2013], М. Хайдеггером (Бытие и время) [Хайдеггер 2002] та Г. Гачевим (Национальные образы мира: Космо - Психо - Логос) [Гачев 1995] об'єднав їх в архетипний універсальний концепт 'Дім - Поле - Храм', доречно застосувавши для аналізування явищ української культури, зокрема й відображених у художніх творах (як відомо, література є відповідною науковою галуззю й одночасно транслятором культури). Зазначені узагальнені топоси буття помітні в українській літературі (особливо прозі та епічній поезії) доби романтизму, як, скажімо, у творах П. Куліша, Г. Барвінок, О. Стороженка та інших письменників, що простежено в монографії авторки цієї розвідки Фольклоризм украӥнської романтичної прози [Янковська 2016].

Перші рядки поеми Т.Шевченка Наймичка чітко, як для твору такого формату, і водночас типово-узагальнено репрезентують картину простору національного буття: У неділю вранці-рано / Поле крилося туманом; / У тумані, на могилі, / Як тополя, похилилась / Молодиия молодая [...] [Шевченко 1985: 240]. Ключові лексеми поле, могила, тополя, що відразу візуалізують окреслений простір, і людина (молодиия молодая), яка $\epsilon$ центром цього простору, оживлює його своєю присутністю, разом вони репрезентують певний етнічно-ментальний просторовий локус. І все це настільки лаконічно та містко зображено, що відбувається ніби “згущення” слова, думки та уяви (унаочнення), крізь призму яких читач ніби стає безпосереднім спостерігачем зображуваного та “вмикає”" свої почуття, емоцію, співпереживання, які не залишають його до кінця прочитання поеми (порівняння відображених у поемі та повісті Наймичка Т. Шевченка етнобуттєвих топосів 'Дім', 'Поле' та 'Храм' може бути наступним етапом у компаративних студіях з вивчення цих творів).

Натомість в однойменній російськомовній повісті письменник дещо надмірно конкретизує цей простір (очевидно, орієнтується на думки російського 
читача), змінюючи стиль оповіді від народно-нараторського, притаманного українським творам доби романтизму, до художньо-авторського, з украпленням публіцистичного чи навіть науково-популярного, як під час описування курганів на Ромодановому шляху від Ромен до Кременчуга: Нередко виднеются и курганы, совершенно круглые, сажен 50 в диаметре. Есть и больше, и меньше, всегда с выходами: двумя, тремя и четырьмя, смотря по величине кургана. Их простой народ называет просто могилами. Есть и такие насыпи (и это самые большие), которых и форму определить нельзя. Это валь разной величины и в разных направлениях [Шевченко 1978, 3: 54]. Тут же простежуємо багато відступів від основної сюжетної лінії та порівнянь, зокрема географічно різних територій [див.: Шевченко 1978, 3: 58]. Не зовсім гармоніює зі стилем повісті також майже маніфестаційний заклик письменника: О агрономы-филантропь!! Вылумайте вы вместо серпа какую-нибудь другую машину. Вы этим окажете величайщую услугу обречённому на тяжёльиитруд человечеству [Шевченко 1978, 3: 56]. Так само неорганічно сприймаються окремі переклади українських слів, як, скажімо, звертання молодої шинкарки до чумаків „господа чумаче”, що, очевидно, звучало як „панове чумаки” [Шевченко 1978, 3: 53]. Російська лексема господа семантично не завжди відповідає українській лексемі панове. Натомість у поемі стиль витриманий рівномірно протягом усього твору. Зрештою, цю думку висловлює у своєму викладі й І. Франко, наголошуючи, що „всі критики, котрі доторкалися творів Шевченка, згідно називають «Наймичку» одною 3 його найкращих поем”, „геніальним надбанням вселюдської літератури”, а її визначною рисою „простоту і натуральність”, коли „все здається таке ясне, так природно з собою пов'язане, а потім висказане так просто і безпретенсіонально, немов кожний епізод, кожде слово поеми вихоплене прямо з душі читача [...]" [Франко 1981, 29:447].

Пізніше, завершуючи свій опис, учений усе-таки безапеляційно наголошує на перевазі експозиції поеми над повістю, чим навіть дещо суперечить своїм попереднім думкам, порівн.: „Поет тут і там снує ту саму провідну думку, та в поемі висказує iï коротко, без усіх лишніх подробиць, але способом таким пластичним та ясним, а при тім в такім зв'язку з попередньою рефлексією, що тих кілька рядків робить далеко глибше і суцільніше враження, ніж аналогічна сцена в повісті, де реалізм подробиць шкодить суцільності враження", бо, як резюмує він далі, „поезія — то згущена, сконцентрована, скристалізована дійсність” [Франко 1981, 29: 457]. Хоч і про Шевченкову прозу, зокрема й повість Наймичка, дослідник висловлюється не менш схвально, зазначаючи, що це „,його адорація штуки”, яку вважає „чимсь божественним, вічним, чимсь таким, до чого треба приступати з побожним трепетом" [Франко 1981, 29: 463]. Учений переконливо доводить, що в цьому творі поет намагається піднести „життєвий факт в ясну сферу ідей”, і цей факт дійсності, „вірно заобсервований і вміло вхоплений”, намагається „перетворити в тип, скристалізувати 
в символічний образ самої ідеї”, тому, на його думку, Шевченків реалізм тут зливається 3 ,ідеалізмом” [Франко 1981, 29: 464].

Стосовно першого опублікування поеми дослідник зазначив, що „,[...] в p. 1860 «Наймичка» напечатана була в Петербурзі осібною брошуркою-метеликом" [Франко 1981, 29: 449], а в Коментарях, уже в час видання 29-го тому найповнішого на сьогодні зібрання праць I. Франка у 50-ти томах доповнено, що „вдруге за життя поета поема «Наймичка» була надрукована в «Кобзарі» 1860 р.” [Коментарі, Франко 1981, 29: 634]. При цьому зовсім не згадується про те, що вперше зазначена поема Т. Шевченка була надрукована ще 1857 р. в другому томі Записок о Южной Руси П. Куліша без зазначення імені автора поеми та 3 коментарями видавця [Записки о Южной Руси 1857, 2]. Припускаємо, що I. Франко міг опустити цей факт, а за радянських часів зазначена Кулішева праця була заборонена як націоналістична та вилучена 3 бібліотек, і про неї не згадували (репринтне перевидання Записок... відбулося вже за часів незалежності однією книгою 1994 р.) [Записки... 1994, 2]. Наукове перевидання цієї праці з упорядкуванням, підготуванням тексту й коментарями В. Івашківа здійснене в 2015 р. в межах проекту повного опрацювання та видання творів письменника, який триває ще й досі [Куліш 2015, III, 2].

Про мову написання повісті та поеми в згаданій вище цитаті I. Франко зауважив, що вона була написана „мовою російською, густо перемішаною зворотами українськими" [Франко 1981, 29: 447] (натомість поема написана доброю українською літературною мовою 3, можна сказати, делікатними та доречними вкрапленнями одиниць розмовно-побутового стилю). Зазначмо, що такою самою мовою, як у повісті Т. Шевченка, написані, напр., ще Вечори на хуторі біля Диканьки М. Гоголя. Ужиті українізми тогочасні критики іноді (спочатку) вважають “помилками”, ніби опосередковано натякаючи на недосконале володіння авторами російською мовою чи невдалий переклад. Проте вже пізніше українськими (та й російськими) літературознавцями було констатовано, що це був умисний стилістичний письменницький прийом, і саме за допомогою цих “помилок” авторам удалося надати своїм творам національного колориту, вони отримали оригінальне звучання, яким збагатили й російську мову, стали більш зрозумілими не лише для інтелігенції, але й для широкого кола читачів. За допомогою таких мовних прийомів письменники творять особливий стиль оповіді, хоч і російською мовою, але зовсім не схожий на стиль тогочасних російських письменників. Для того, аби уявити, що саме не перекладав Т. Шевченко в повісті Наймичка, подамо хоча б неповний перелік цих українізмів: іменники - вечеря, возивня, гай (іноді вдається до перекладу - рощца), гайдамака (жартома Яким каже про Марка, коли той пустує), вихи, жито, загороды, килимок, клуня, козак, комора, кожух, крыныия, кургани, ледащуо, лёх, молодищза (у значенні 'молода жінка'), мозючки ('місцева назва дитячої страви з білого хліба з молоком’), макогон, образы, ослон, 
пасика, призба, пропасныця, рогач, свита, сины, скороспелка-кольскка, хата, чуб, чумак, шлях; дієприслівники з українськими суфіксами - взглянувши, проводивши, похоронивши, походивши, сказавши; російські дієслова з українським суфіксами та закінченнями - проводив, похоронив, сказав, походив, посмотримо, помремо. Виявляємо й інші приклади використання українізмів, що являють собою відповідні синтаксичні конструкції, морфологічні чи фонетичні форми: дытылна плаче замість ребёнок плачет; ходимо замість пойдём; единому сыну замість единственному сыну; по иерквам замість по церквям; ричка замість речка, яблуня замість яблоня. Розмову Лукії та московки передано російським шрифтом, але повністю по-українськи: - Добрывечир! Добрывечир! - едва отвечало ей что-то. Лукия ощупала тряпки, а в тряпках завёрнуто что-то живое. - Нездужаю; стара, погана, погана стала. - Чи нема у вас лою, я б каганець засвитыла. - Ничого нема. И печь не топлена. я позавчора ходила в гости, воротилася додому та й занедужала [Шевченко 1978, 3: 94].

Цікаво, що І. Франко подає фрагмент повісті Наймичка із зображенням полудня на хуторі повністю в перекладі українською мовою, що насправді звучить і сприймається принадніше, більш органічно, оскільки зображена картина етнічно колоритна. Хоч наголосімо, що Т. Шевченко й російськомовним текстом зумів викликати національні інтенції, що передаються через осягнення ключових сутностей буття, “тут-буття”, відображеного у творі, що є стрижневим, притаманним українцям загалом, $і$ які під впливом різноманітних чинників можуть трансформуватися, але не втрачають свого смислонаповнення. Причини використання Кобзарем російської мови для написання прозових, окремих поетичних творів, листів і навіть щоденника (Журналу) дослідила та систематизувала Т. Космеда у своїй розвідці Лінгвістичні експерименти Т. Шевченка, або загадка, чому російська мова обрана мовою письменницького щзоденника (до 200-ліття від дня народж. письменника) [Космеда 2015: 105-112], наголошуючи на “російськомовній креативності” поета [Космеда 2015: 106].

У своєму габілітаційному викладі І. Франко також порівнює двох героїнь зі згаданих вище поем Т. Шевченка - наймичку Ганну та Катерину з однойменної поеми. Про Ганну він справедливо зазначає: „Наймичка — натура безмірно глибша, чуття у неї не тільки живе, але сильне та високе, любов до дитини така могуча, що перемагає все інше, заслонює перед нею весь світ, заставляє забути про себе саму, віддати все своє життя не для хвилевої покути, але для довгої жертви на користь своєї дитини" [Франко 1981, 29: 468-469]. У протистоянні постають безвихідь та шукання виходу в однаковій ситуації, хоч і способом високої жертовності; крах особистості під вагою обставин та незламність духу; безмірна сила любові. У відповідь Д. Шейковському I. Франко пише про те, що Наймичка - не тип, оскільки це дуже 
“рідкий” випадок, аби українка підкидала комусь своє дитя (хіба „во благо самої дитини"). Саме опис таких виняткових фактів, на його думку, і створює справжню літературу [Франко 1981, 29: 465-466]. “Покритництво” в описаний Т. Шевченком час у звичаєвому суспільстві було явищем насправді винятковим, що мало певні моральні регулятиви в межах звичаєвого права, тому митець і приділив йому стільки уваги.

У наш час відмова батьків від дочки-покритки видається вчинком невиправдано жорстоким. Але Т. Шевченко, спираючись на устої звичаєвого права, не заперечує їх, а лише констатує факти, що помітив і високоповажний дослідник, коли зазначив: „Шевченко не протестував проти нелюдськості такого народного погляду, може, вважаючи його гарантією заховання чистоти і моральності в українськім народнім житті. Та він умів находити глибокі, зворушливі тони, щоби змалювати наслідки того погляду" [Франко 1981, 29: 465]. I. Франко акцентує також на відмінності в зображенні хуторянина Якима (у повісті), відзначаючи, що його постать “обрисована дуже гарно”, тоді, коли відповідний образ у поемі “ледве тільки нашкіцований” [Франко 1981, 29: 453]. Тим самим учений наголошує на “іншості” Т. Шевченка як прозаїка і як поета. У повісті він виступає як реаліст, а в поемі — як лірик, романтик, що засвідчують належність цієї поеми до романтизму, стиль її викладу, що апелює до переданого в римованому варіанті народного наративу, і змалювання образів та й інші характерні риси. Наголосімо, що відмінність у стилі написання цих творів надзвичайно відчутна.

Зазначмо, що між повістю й поемою існують відмінності й фабульного характеру. Наприклад, у поемі відсутня міфологізована розповідь про жінку в степу на могилі, про яку господарям розповідала “челядь"; зовсім не йдеться про навчання Марка в школі, стосунки Якима та Марти зі священиком із сусіднього села, московку (у якої зупиняється Лукія, коли приїздить у рідне село), про обряд обжинок (якому в повісті приділено достатньо уваги, хоч й описано дещо романтично-ідеалізовано). Загалом змалювання "падіння" Лукії від красуні-,Цариці” в обжинковому вінку, доброї та слухняної доньки своїх достойних і заможних батьків, до покритки - ефектний прийом, який Т. Шевченко, використав у повісті. Але це “падіння” стало й своєрідним “піднесенням" героїні над соціумом, обставинами й навіть над собою. Можна порівнювати й багато інших епізодичних сцен та подій, зображення яких відрізняються в поетичному та прозовому текстах.

Акцентуємо й на відмінностях під час зображення “улана"-москаля (автор навіть не називає його імені, можливо, так виказуючи зневагу до нього), батька Марка, який у поемі проходить лише епізодично, але в повісті описаний детально. Завваживши це, I. Франко написав, що „в своїй «Катерині» виспівав Шевченко так глибоко і голосно деморалізаційний вплив московської солдатчини на вкраїнський сільський люд, що тут (у поемі Наймич- 
$\kappa a$ - Ж. Я.), мабуть, не хотів сього повторяти і волів сю часть експозиції лишити зовсім на боці" [Франко 1981, 29:452]. "Улан” у повісті зображений як активний персонаж, відрізок його життя в кілька років від зустрічі 3 Лукією до виходу з військовою частиною в похід подано окремою лінією, 3 детально виписаним характером, поглядами, навіть іншою (“московською”) ментальністю. Лукія мало не піддається його благанням відновити стосунки, бо в душі й досі кохає його. Уникнувши цього, вона малює у своїй уяві можливе страшне майбутнє, що буквально перегукується зі словами Наума Дрота 3 повісті Маруся Г. Квітки-Основ'яненка, коли він не хоче віддати доньку Марусю за Василя, поки той не відкупиться від солдатчини, бо доля солдатки йому була відома, порівн.: Ні жінка, ні удова; звісно, як солдаток шанують; як саму послідню паплюгу, i ніхто й не вірить, щоб була салдатка, та й чесна [...]. Де їй за полками таскатись? А молоде, дурне, попадеться ледачим людям, навернуть на усе злеє. Худобу розтаскають, повіднімають, хто ї̈ защитить? Діточки без доглядання, у бідності, у нищеті, без науки, без усього помруть або - не дай боже! - бездільниками стануть. А вона затим ізстаріється, немощі одоліють, бідність, калічество ... тільки що в шпиталь, до стариів! [Квітка-Основ'яненко 1981, 3: 56]. Порівняймо також опис долі солдатки у творі Т. Шевченка: Каких усилий, какого тяжкого труда ей стоило переломить себя! И только одна благородная любовь матери спасла тебя от разверзавшейся в другой раз перед тобою пропасти. Без высокой любви пошла бы ты за эскадроном, как ходят тысячи тебе подобныхх. Сначала твой мыльий-чернобрывый остриг бы тебя и одел мальчиком (как сердечную Оксану), чтобы скрыть твой пол от товарищей, а через месяи он перестал бы тебя и скрывать, а на другой - играла бы тобою пьяная молодёжь на бивуаках. На третий - ты бы для них устарела и опротивела, потому что ты опять забеременела, и возили б тебя вместе с дорогими собаками в телеге, потому что от тебя отвязаться нельзя, а тебе приютиться негде, кроме уланского обоза [...] [Шевченко 1978, 3: 101]. Як бачимо, у Кобзаря картина життя солдатки показана розлого, натуралістично, від імені автора, а не самої героїні, тому звучить більш патетично, ніж із уст Наума Дрота.

Насамкінець зауважимо, що порівняльні студії для пізнання творчого методу письменника $є$ досить ефективними. У цій статті ми зупинилися тільки на окремих, найбільш цікавих епізодах габілітаційного викладу I. Франка стосовно двох зазначених однойменних творів Т. Шевченка (поеми та повісті Наймичка) з метою розставити деякі акценти, уточнити окремі судження й факти (як дата й послідовність написання аналізованих творів), подивитися на порівнювані вченим явища з урахуванням методології сучасної гуманітаристики й фактично накреслити напрямки можливих подальших компаративних студій, які пунктирно простежуємо вже й у виголошеній лекції вченого. 
Уважаємо, що таке повернення до праць українських (і не лише) класиків, 3 урахуванням нинішніх вимог до аналізу художніх текстів, дає цим дослідженням “друге життя”, доводячи їхню непересічність у час написання, а також значення для поступування української гуманітарної науки загалом та літературознавства зокрема в подальші часи аж до сучасності.

Отже, обираючи різні критерії для аналізу, І. Франко надає перевагу то поемі, то повісті Кобзаря, критикуючи слабкі місця й наголошуючи на сильних. Зазначмо, що ці твори, маючи фактично однакову основну сюжетну лінію, разом з тим, дуже різні, й не лише за способом викладу змісту (поетичним та прозовим). Важко не помітити стилістичну однорідність, внутрішню підпорядкованість, лапідарність, лаконізм поеми при влучності та економному використанні художніх засобів, що доведена поетом до найвищого ступеня досконалості. Поема Наймичка Т. Шевченка репрезентує романтизм у всіх його найпривабливіших рисах. Однойменна повість письменника, хоч іє для свого часу не менш знаковою, стилістично репрезентує помежів'я романтизму та реалізму. Уважаємо, що саме це увиразнює іiі стилістичну неоднорідність. Розлогі, майже документальні описи, що не сприяють розвитку уяви, російськомовний текст при зображенні глибоко національних явищ дійсності (як згадувалося, навіть I. Франко у своїй лекції частину тексту повісті подає українською мовою) - це неповний перелік рис, що дають право ставити повість на друге місце за мистецьким рівнем викладу порівняно з поемою, але одночасно на високе місце в розвитку української російськомовної прози, що в перш. пол. - сер. XIX ст. було явищем непоодиноким і ще чекає на прискіпливе дослідження.

Розпочаті компаративні студії в зазначених напрямках можна поглибити, особливо на рівні фабульних порівнянь, а також на рівні відображення в зазначених творах національних топосів буття й архетипних складників, що маємо за перспективу.

\section{Список використаної літератури}

Гачев Г., Национальные образы мира: Космо - Психо - Логос, Москва: Прогресс Культура, 1995.

Записки о Южной Руси, в 2 томах, сост., авт. предисл., примеч. П. А. Кулиш, СПб 1857, т. 2. Записки о Южной Руси, в 2 томах, т. 1, т. 2 в одной книге, сост. и изд. Пантелеймона Кулиша, Киев: Днипро, 1994 (Репринт 1856-1857 гг.).

Коментарі. „Наймичка” Т. Шевченка: виклад габілітаційний, виголошений у Львівськім університеті 18 лютого 1895 року, [в:] І. Франко, Зібр. тв., у 50 томах, Київ: Наукова думка, 1981, т. 29, с. 634-635.

Космеда Т., Лінгвістичні експерименти Т. Шевченка, або загадка, чому російська мова обрана мовою письменницького щоденника (до 200-ліття від дня народж. письменника), [в:] „Studia Ukrainica Poznaniesia”, 2015, zesz. III, s. 105-112. 
Кримський С. Б., Архетипи української культури, [в:] Його ж, Під сигнатурою Софії, Київ: Видавничий дім „Києво-Могилянська академія”, 2008, с. 301-319.

Кримський С., Архетипи украӥнської ментальності, [в:] Його ж, Проблеми теорії ментальності, Київ: Наукова думка, 2006, с. 273-301.

Кримський С., Дім - Поле - Храм, [в:] Його ж, Про софійність,правду, смисли людського буття: зб. наук.-публ. і філос. ст., Київ: ІФНАНУ, 2010, с. 426-439.

Куліш П., Повне зібр. тв. Наук. праці. Публічистика, упоряд ст., комент. В. Івашків, Київ: Критика, 2015, т. III, кн. 1, 2.

Наймичка (Т. Шевченка), [в:] П. Куліш, Повне зібр. тв. Наук. пращі. Публіцистика, упоряд. ст., комент. В. Івашків, Київ: Критика, 2015, т. ІІІ, кн. 2, с. 104-115.

Франко І., „Наймичка” Т. Шевченка: виклад габілітаційний, виголошений у Львівськім університеті 18 лютого 1895 року, [в:] Його ж, Зібр. тв., у 50 томах, Київ: Наукова думка, 1981, т. 29, с. 447-469.

Хайдеггер М., Бытие и время, пер. с нем. В. В. Бибихина, СПб.: Наука, 2002.

Юнг К. Г., Архетипи і колективне несвідоме, пер. $з$ нім. К. Котюк, наук. ред. укр. вид. О. Фешовець, Львів: Астролябія, 2013.

Янковська Ж., Фольклоризм украӥнської романтичної прози, Львів: НВФ „Українські технології”, 2016.

\section{Spysok vykorystanoi literatury [References]}

Gachev G., Nacional'nye obrazy mira: Kosmo - Psixo — Logos [National Images of the World: Cosmo — Psycho — Logo], Moskva: Progress - Kultura, 1995.

Zapiski o Yuzhnoj Rusi [Notes on Southern Russia], v 2 tomax, sost., avt. predisl., primech.

P. A. Kulish, SPb 1857, t. 2.

Zapiski o Yuzhnoj Rusi [Notes on Southern Russia], v 2 tomax, t. 1, t. 2 v odnoj knige, sost. i izd. Pantelejmona Kulisha, Kiev: Dnipro 1994 (Reprint 1856-1857 gg.).

Komentari. „Naimychka” T. Shevchenka: vyklad habilitatsiinyi, vyholoshenyi u Lvivskim universyteti 18 liutoho 1895 roku [Comments. T. Shevchenko's ,Naimychka”: Habilitation Lecture, Presented at Lviv University on February 18, 1895], [v:] I. Franko, Zibr. tv., u 50 tomakh, Kyiv: Naukova dumka, 1981, t. 29, s. 634-635.

Kosmeda T., Linhvistychni eksperymenty T. Shevchenka, abo zahadka, chomu rosiiska mova obrana movoiu pysmennytskoho shchodennyka (do 200-littia vid dnia narodzh. pysmennyka) [T. Shevchenko's Linguistic Experiments, ortheRiddle Why the RussianLanguage was Chosen as the Language for the Writer's Diary (in Commemoration of the Writer's 200 th Anniversary)], [v:] „Studia Ukrainica Poznaniesia”, 2015, zesz. III, s. 105-112.

Krymskyi S. B., Arkhetypy ukrainskoi kultury [Archetypes of Ukrainian Culture], [v:] Yoho zh, Pid syhnaturoiu Sofii [Under Sofiia Signature], Kyiv: Vyd. dim "Kyievo-Mohylianska akademiia”, 2008, s. 301-319. 
Krymskyi S., Arkhetypy ukrainskoi mentalnosti [The Archetypes of Ukrainian Mentality], [v:] Yoho zh, Problemy teorii mentalnosti [Issues of Mentality Theory], Kyiv: Naukova dumka, 2006, s. 273-301.

Krymskyi S., Dim - Pole - Khram [Home - Field - Temple], [v:] Yoho zh, Pro sofiinist, pravdu, smysly liudskoho buttia: zb. nauk.-publ. i filos. statei [On Sophicality, Thuth, Purpose of Human Existence: the Collection of Scientific Publications and Philosophical Papers], Kyiv: IFNANU, 2010, s. 426-439.

Kulish P., Povne zibr. tv. Naukovi pratsi. Publitsystyka [Complete Collection of Works. Scientific Papers. Social Essays], uporiad st., koment. V.Ivashkiv, Kyiv: Krytyka, 2015, t. III, kn. 1, 2.

Naimychka [The Servant Girl] (T. Shevchenka), [v:] P. Kulish, Povne zibr. tv. Naukovi pratsi. Publitsystyka [Complete Collection of Works. Scientific Papers. Social Essays], uporiad. st., koment. V. Ivashkiv, Kyiv: Krytyka, 2015, t. III, kn. 2, s. 104-115.

Franko I., „Naimychka” T. Shevchenka: vyklad habilitatsiinyi, vyholoshenyi u Lvivskim universyteti 18 liutoho 1895 roku [T. Shevchenko's ,, The Servant Girl”: Habilitation Lecture, Presentedat Lviv University on February 18, 1895], [v:] Yoho zh, Zibr. tv., u 50 tomakh, Kyiv: Naukova dumka, 1981, t. 29, s. 447-469.

Xajdegger M., Bytie i vremya [Existence and Time], per. s nem. V. V. Bibixina, SPb.: Nauka. 2002.

Jung K. G., Arkhetypy i kolektyvne nesvidome [Archetypes and Collective Unconscious], per. z nim. K. Kotiuk, nauk. red. ukr. vyd. O. Feshovets, Lviv: Astroliabiia, 2013.

Yankovska Zh., Folkloryzm ukrainskoi romantychnoi prozy: monohrafiia [Folklorism of Ukrainian Romanti Prose: Monograph], Lviv: NVF „Ukrainski tekhnolohii”, 2016.

\section{Список використаних джерел}

Квітка-Основ’яненко Г. Ф., Маруся, [в:] Його ж, Зібр. тв., у 7 томах, т. 3: Прозові твори, Київ: Наукова думка, 1981, с. 21-87.

Шевченко Т., Наймичка, [в:] Його ж, Кобзар, Київ: Дніпро, 1985, с. 240-251.

Шевченко Т., Наймичка, [в:] Його ж, Твори, у 5 томах, т. 3. Драматичні твори. Повісті, Київ: Дніпро, 1978, с. 52-121.

\section{Spysok vykorystanykh dzherel}

Kvitka-Osnovianenko H. F., Marusia [Marusia], [v:] Yoho zh, Zibr. tv., u 7 tomakh, t. 3: Prozovi tvory, Kyiv: Naukova dumka, 1981, s. 21-87.

Shevchenko T., Naimychka [The Servant Girl], [v:] Yoho zh, Kobzar [Kobzar], Kyiv: Dnipro, 1985, s. 240-251.

Shevchenko T., Naimychka [The Servant Girl], [v:] Yoho zh, Tvory v 5 tomakh [Works in 5 Volumes], t. 3. Dramatychni tvory. Povisti [Dramatic Works. Novelettes], Kyiv: Dnipro, 1978, s. 52-121. 